\title{
Genetic Diversity of Orobanche cumana Populations in Serbia
}

\author{
Žarko Ivanović $\mathbb{D}^{1 *}{ }^{1 *}$, Dragana Marisavljević ${ }^{1}$, Radovan Marinković ${ }^{2}$, Petar Mitrović ${ }^{2}$, Jovana Blagojević \\ Ivan Nikolić ${ }^{3}$, and Danijela Pavlović ${ }^{1}$ \\ ${ }^{1}$ Institute for Plant Protection and Environment, 11000 Belgrade, Serbia \\ ${ }^{2}$ Institute of Field and Vegetable Crops, 21000 Novi Sad, Serbia \\ ${ }^{3}$ Faculty of Biology, University of Belgrade, 11000 Belgrade, Serbia
}

(Received on April 29, 2021; Revised on July 6, 2021; Accepted on August 12, 2021)

In this study, we report genetic characterization of Orobanche cumana, the causal agent of sunflower wilting in Serbia. The genetic diversity of this parasitic plant in Serbia was not studied before. Random amplified polymorphic DNA (RAPD) markers and partial $r b c L$ gene sequences analysis were used to characterize the O. cumana populations at the molecular level. While phylogenetic analyses of RAPD-PCR amplicons were performed using unweighted pair-group Method analyses, $r b c L$ gene sequences were analyzed using neigbor joining method and minimum spanning tree. Molecular analyses of RAPD-PCR analysis revealed high genetic diversity of $O$. cumana populations which indicated high adaptive potential of this parasitic weed in Serbia. Further analyses of $r b c L$ gene using minimum spanning tree revealed clear differences among diverse sections of Orobanche genus. Although this molecular marker lacked the resolution to display intrapopulation diversity it could be a useful tool for understanding the evolution of this parasitic plant. Our results suggested that $O$. cumana has great genetic potential which can lead to differentiation of more virulent races which is

*Corresponding author.

Phone) +381-11-2660-049, FAX) +381-11-2669-860

E-mail) zarko.ivanovic@izbis.bg.ac.rs

ORCID

Žarko Ivanović

http://orcid.org/0000-0002-4132-1367

Handling Editor : Eui-Hwan Chung

(cc) This is an Open Access article distributed under the terms of the Creative Commons Attribution Non-Commercial License (http:// creativecommons.org/licenses/by-nc/4.0) which permits unrestricted noncommercial use, distribution, and reproduction in any medium, provided the original work is properly cited.

Articles can be freely viewed online at www.ppjonline.org. important for determining crop breeding strategies for their control.

Keywords : intrapopulation variation, phylogeny, RAPD, $r b c L$, sunflower broomrape

Orobanche cumana Wallr. (broomrape) is a holoparasitic plant found as the main parasitic plant on sunflower roots in many countries, causing severe yield losses in sunflower crops (Fernandez-Aparicio et al., 2016; Pineda-Martos et al., 2013). Successful infection of $O$. cumana suppress host defense responses and turned host roots to a source for efficient nutrient for the parasite (Yang et al., 2020). They are native primarily in the Mediterranean region (i.e., North Africa, the Middle East, and southern Europe), as well as western Asia, where they cause significant crop damage (Parker and Riches, 1993). O. cumana has seriously devastated sunflower producing countries in central and eastern Europe as well as Mediterranean countries causing great economic losses (Calderón-González et al., 2019). In Serbia, broomrape was first discovered in 1951 by Aćimović (1977) and has appeared almost every year with varying intensity since then (Maširević and Medić-Pap, 2009).

In Serbia, O.cumana can be found in the different areas where sunflower is intensively cultivated, primarily in Bačka and Banat regions (Maširević and Medić-Pap, 2009). Due to drastic reduction in morphological characters commonly used in taxonomic identification, difficulties in species identification within the genus Orobanche are recognized (Manen et al., 2004). Recently a new race of $O$. cumana was dicovered with no difference with other $\mathrm{O}$. $\mathrm{Cu}$ mana races, but with ability to parasitize beside sunflower and with host-range expanding to Solanaceae crops (Dor et al., 2020). In order to get better identification of O. cumana 
species molecular identification is necessary.

To improve species identification and phylogenetic studies molecular analyses of several plastid genes were conducted (Manen et al., 2004; Wolfe and dePamphilis, 1997; Young et al., 1999). Molecular studies on genetic diversity within and among populations of $O$. cumana were performed in Spain (Castejón-Muñoz et al., 1991; Malek et al., 2017; Martín-Sanz, 2016; Pineda-Martos et al., 2013), as well as between population from Romania, Bulgaria, and Turkey (Gagne et al., 1998). Genetic studies of $O$. cumana diversity and race composition were performed in Tunisia, Turkey, and Moldova (Bilgen et al., 2019; Duca et al., 2017, 2019; Jebri et al., 2017). The random amplified polymorphic DNA (RAPD) markers are often used to detect variability within an Orobanche population (Atanasova et al., 2005; Katzir et al., 1996; Paran et al., 1997; Williams et al., 1990). Polymorphic amplification products were found useful in detection of small genetic differences among individuals and in distinguishing populations (Gagne et al., 1998; Joel et al., 1998; Roman and Rubiales, 1999). The genus Orobanche consists of 170 species, grouped in four sections: sect. Orobanche (=sect. Osproleon Wallr.), sect. Trionychon Wallr., sect. Gymnocaulis Nutt., and sect. Myzorrhiza (Philippi) Beck. (Manen et al., 2004). Orobanche species were also investigated using the $r b c L$ nucleotide sequence as a molecular marker for identification and better understanding of phylogenetic relations (Benharrat et al., 2000; Manen et al., 2004; Wolfe and de Pamphilis, 1997).

To study variability within and between populations of O. cumana, genetic DNA variations among individuals were investigated, using RAPD markers and $r b c L$ gene sequences. The tested hypotheses were that (1) there is a genetic diversity in the $O$. cumana population from Serbia since growing areas of sunflower are located in diverse geographical regions and (2) analysis of partial $r b c L$ gene sequences could provide better understanding of genetic relatedness among $O$. cumana collected in Serbia and with different Orobanche species.

\section{Materials and Methods}

Plant material. O. cumana plants were collected from infested sunflowers in the main agricultural sunflowergrowing areas in four districts and 11 locations in Serbia (Table 1). Three fields were sampled per location, and for each field from 50 to 300 mature O. cumana plants were collected at equal distances across a diagonal transect of the field. Plants collected in one or three fields in the same locality were assigned as population. Samples were placed
Table 1. Area of origin and codes of Orobanche cumana populations used in study

\begin{tabular}{lccc}
\hline Area of origin & Districts & Location & Code \\
\hline Eastern Serbia & Bor District & Negotin & OC-3 \\
Northern Serbia & South Banat & Vršac & OC-2 \\
Northern Serbia & North Bačka & Subotica & OC-4 \\
Northern Serbia & North Bačka & Subotica & OC-7 \\
Northern Serbia & North Bačka & Subotica & OC-10 \\
Northern Serbia & North Bačka & Feketić & OC-6 \\
Northern Serbia & North Bačka & Feketić & OC-9 \\
Northern Serbia & North Bačka & Feketić & OC-12 \\
Northern Serbia & West Bačka & Kula & OC-5 \\
Northern Serbia & West Bačka & Kula & OC-8 \\
Northern Serbia & West Bačka & Kula & OC-11 \\
\hline
\end{tabular}

in separate paper bags and stored in a field refrigerator at $4^{\circ} \mathrm{C}$ until returning to the lab. Seeds were separated from the plants and stored in glass jars at $4^{\circ} \mathrm{C}$ in the dark.

DNA extraction, amplification, and electrophoresis. Genomic DNA was extracted from plant dried material using DNeasy Plant Mini Kit (Qiagen, Valencia, CA, USA) following manufacturer protocol. Most $r b c L$ sequences were amplified with primers RH1 and 1352R (Wolfe and dePamphilis, 1997). PCR reactions were performed in a volume of $25 \mu \mathrm{l} \mathrm{PCR}$ reaction mixture for $r b c \mathrm{~L}$ consisted of $0.64 \mu \mathrm{M}$ of each primer, $1 \mathrm{U}$ Taq polymerase buffer (50 $\mathrm{mM} \mathrm{KCl}, 10 \mathrm{mM}$ Tris-HCL pH 9.0, 0.1\% Triton X-100; Promega, Madison, WI, USA), $2.0 \mathrm{mM}$ dNTPs, $2.0 \mathrm{mM}$ $\mathrm{MgCl}_{2}$, and 0.0125 units of Taq DNA polymerase (Promega) and $30 \mathrm{ng}$ of genomic DNA. PCR conditions were set according to the protocol described by Wolfe and dePamphilis (1997).

The resulting PCR products were separated by electrophoresis on $1 \%$ agarose gels in $0.5 \times$ TAE buffer for $2 \mathrm{~h}$ at $5 \mathrm{~V} / \mathrm{cm}$ and the amplicons were purified (purification kit, Qiagen) for sequencing (Macrogene, Seoul, Korea). Sequences were compared with other related sequences of O. cumana representatives using BLAST program of NCBI for primary identification. O. cumana sequences were deposited into NCBI GenBank. The list of O. cumana DNA accession numbers and list of different $r b c L$ gene sequences obtained from the NCBI database, including 30 Orobanche species are provided in Table 2.

RAPD analysis. PCR reactions were performed in 25 $\mu 1$ reaction volume containing $30 \mathrm{ng}$ of genomic DNA, $0.2 \mathrm{mM}$ of the dNTPs (Fermentas, Lithuania), $0.5 \mu \mathrm{M}$ of primer, $50 \mathrm{mM} \mathrm{KCl}, 10 \mathrm{mM}$ Tris, $1.5 \mathrm{mM} \mathrm{MgCl}_{2}$, and 1 
Table 2. Orobanche specimens used in this study their geographic origin, reference and GenBank accession numbers

\begin{tabular}{|c|c|c|c|}
\hline Species names & Area of origin & Reference & GenBank accession no. \\
\hline O. cumana $(\mathrm{OC}-2)$ & Vršac & This study & KP222282 \\
\hline O. cumana $(\mathrm{OC}-3)$ & Negotin & This study & KP222283 \\
\hline O. cumana $(\mathrm{OC}-4)$ & Subotica & This study & KP222284 \\
\hline O. cumana $(\mathrm{OC}-5)$ & Kula & This study & KP222285 \\
\hline O. cumana $(\mathrm{OC}-6)$ & Feketić & This study & KP222286 \\
\hline O. cumana $(\mathrm{OC}-7)$ & Subotica & This study & KP222287 \\
\hline O. cumana $(\mathrm{OC}-8)$ & Kula & This study & KP222288 \\
\hline O. cumana $(\mathrm{OC}-9)$ & Feketić & This study & KP222289 \\
\hline O. cumana $(\mathrm{OC}-10)$ & Subotica & This study & KP222290 \\
\hline O. cumana $(\mathrm{OC}-11)$ & Kula & This study & KP222291 \\
\hline O. cumana $(\mathrm{OC}-12)$ & Feketić & This study & KP222292 \\
\hline Orobanche cernua & - & Wolfe and dePaphilis (1997) & U73968 \\
\hline Orobanche cumana & France & Delavault and Thalouran (2002) & AF090349 \\
\hline Orobanche rigens & France & Manen et al. (2004) & AY582259 \\
\hline Orobanche rapum-genistae & France & Manen et al. (2004) & AY582255 \\
\hline Orobanche cf. gracilis & Italy & Manen et al. (2004) & AY582199 \\
\hline Orobanche cumana & France & Delavault and Thalouran (2002) & AF090350 \\
\hline Orobanche coerulescens & Austria & Manen et al. (2004) & AY582190 \\
\hline Orobanche aconiti-lycoctoni & Spain & Manen et al. (2004) & AY582181 \\
\hline Orobanche uniflora & USA & Manen et al. (2004) & AY582180 \\
\hline Orobanche fasciculata & - & Wolfe and dePaphilis (1997) & U73970 \\
\hline Orobanche californica & USA & Manen et al. (2004) & AY582178 \\
\hline Orobanche corymbosa & - & Wolfe and dePaphilis (1997) & U73969 \\
\hline Orobanche alsatica & Austria & Manen et al. (2004) & AY582182 \\
\hline Orobanche amethystea & Spain & Manen et al. (2004) & AY582183 \\
\hline Orobanche artemisiae-campestris & Swityerland & Manen et al. (2004) & AY582184 \\
\hline Orobanche bartlingii & Croatia & Manen et al. (2004) & AY582186 \\
\hline Orobanche caryophyllacea & Georgia & Manen et al. (2004) & AY582187 \\
\hline Orobanche cernua var. cernua & Spain & Manen et al. (2004) & AY582189 \\
\hline Orobanche cernua var. australiana & Australia & Manen et al. (2004) & AY582188 \\
\hline Orobanche crenata & Greece & Manen et al. (2004) & AY582196 \\
\hline Orobanche gracilis & Spain & Manen et al. (2004) & AY582197 \\
\hline Orobanche hederae & France & Manen et al. (2004) & AY582201 \\
\hline Orobanche lutea & Georgea & Manen et al. (2004) & AY582206 \\
\hline Orobanche minor & Greece & Manen et al. (2004) & AY582208 \\
\hline Orobanche pubescens & Greece & Manen et al. (2004) & AY582275 \\
\hline Orobanche teucrii & France & Manen et al. (2004) & AY582269 \\
\hline Orobanche transcaucasica & Georgia & Manen et al. (2004) & AY582272 \\
\hline Orobanche mutelii & France & Manen et al. (2004) & AY582247 \\
\hline Orobanche nana & France & Manen et al. (2004) & AY582248 \\
\hline Orobanche ramosa & Spain & Manen et al. (2004) & AY582251 \\
\hline Orobanche tunetana & Spain & Manen et al. (2004) & AY582273 \\
\hline
\end{tabular}

U of Taq DNA polymerase (Kapa Biosystems, Woburn, MA, USA). The primers used were as follows: OPA 02 (5'-TGCCGAGCTG-3'); OPA 01 (5'-CAGGCCCTTC-3'); OPA 13 (5'-CAGCACCCAC-3'); OPB 01 (5'-GTTTCGCTCC-3'); OPB 10 (5'-CTGCTGGGAC-3') (Moretti et al., 2004). Amplification was carried out in the thermal cycler (Eppendorf, Hamburg, Germany) under the following condition: initial denaturation at $94^{\circ} \mathrm{C}$ for $5 \mathrm{~min}$, followed by 45 cycles at $94^{\circ} \mathrm{C}$ for $1 \mathrm{~min}, 37^{\circ} \mathrm{C}$ for $1 \mathrm{~min}$, and $72^{\circ} \mathrm{C}$ for $2 \mathrm{~min}$, with a final extension at $72^{\circ} \mathrm{C}$ for $5 \mathrm{~min}$. PCR 
products were separated in a $1 \%$ agarose gel in TAE buffer (Tris-acetate $0.04 \mathrm{M}$, EDTA $0.001 \mathrm{M}$ ) at $70 \mathrm{~V}$ for $4 \mathrm{~h}$, visualized under UV light after staining with ethidium bromide and photographed.

Data analysis. The positions of the bands were assessed visually and each amplification band was treated as a unit character and was scored as present (1) or absent (0). The NEIGHBOR software of the PHYLIP computer package (Felsenstein, 1993) was used to create a phylogenetic tree. Distance matrix was constructed by using the mathematical equation proposed by Nei and Li (1979) based on the proportion of shared DNA fragments and the unweighted pairgroup method (UPGMA) with arithmetic means was used for clustering.

To evaluate the phylogenetic relationship between the $O$. cumana population in Serbia and different Orobanche species, the phylogenetic tree was constructed. Neighbor joining (NJ) analyses were performed with nucleotide sequences of partial $r b c L$ gene sequences which were assembled and edited using FINCHTV v.1.4.0 (http://www.geospiza. com). Multiple alignments and comparisons of sequences of different Orobanche species were performed using CLUSTALW integrated into MEGA6 software (Tamura et al., 2013). A bootstrap analysis with 1,000 replications was performed by the same software.

The minimum spanning tree (MST) was generated in SplitsTree software (Huson and Bryant, 2006) by using our

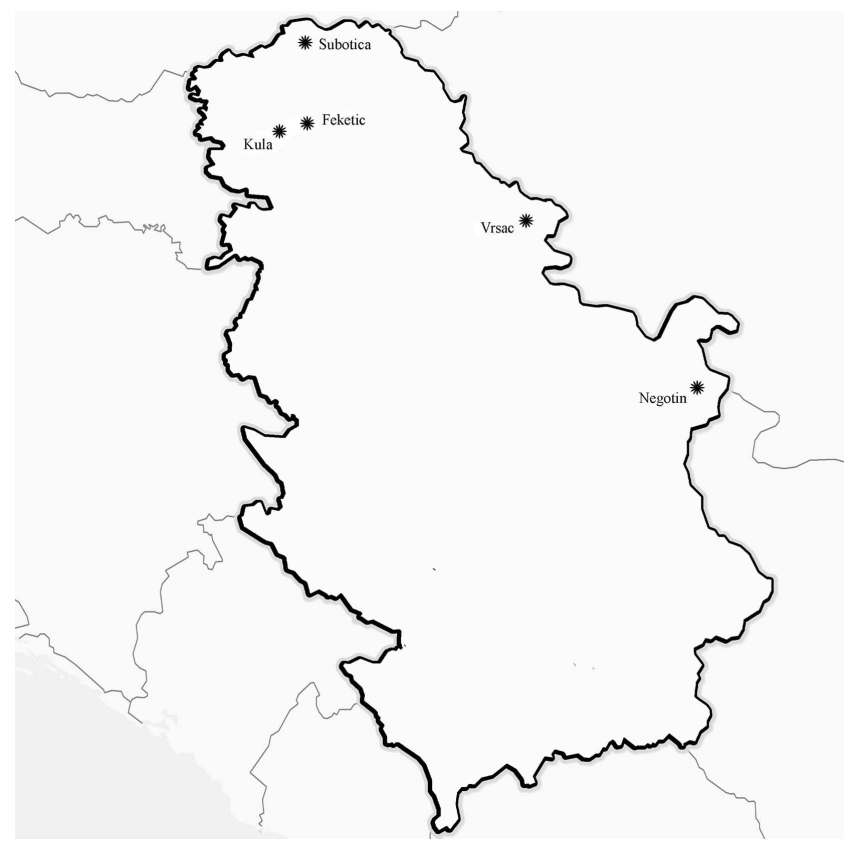

Fig. 1. Map of Serbia showing localities in which Orobanche cumana populations were collected.

sequences and sequences obtained from NCBI database that represents Orobanche species diverse sections. Generated sequences served as the tree nodes. The method estimated a probability of ancestry for each individual species. Individuals were assigned to one cluster or jointly to two or more clusters if their genotypes indicated that they were

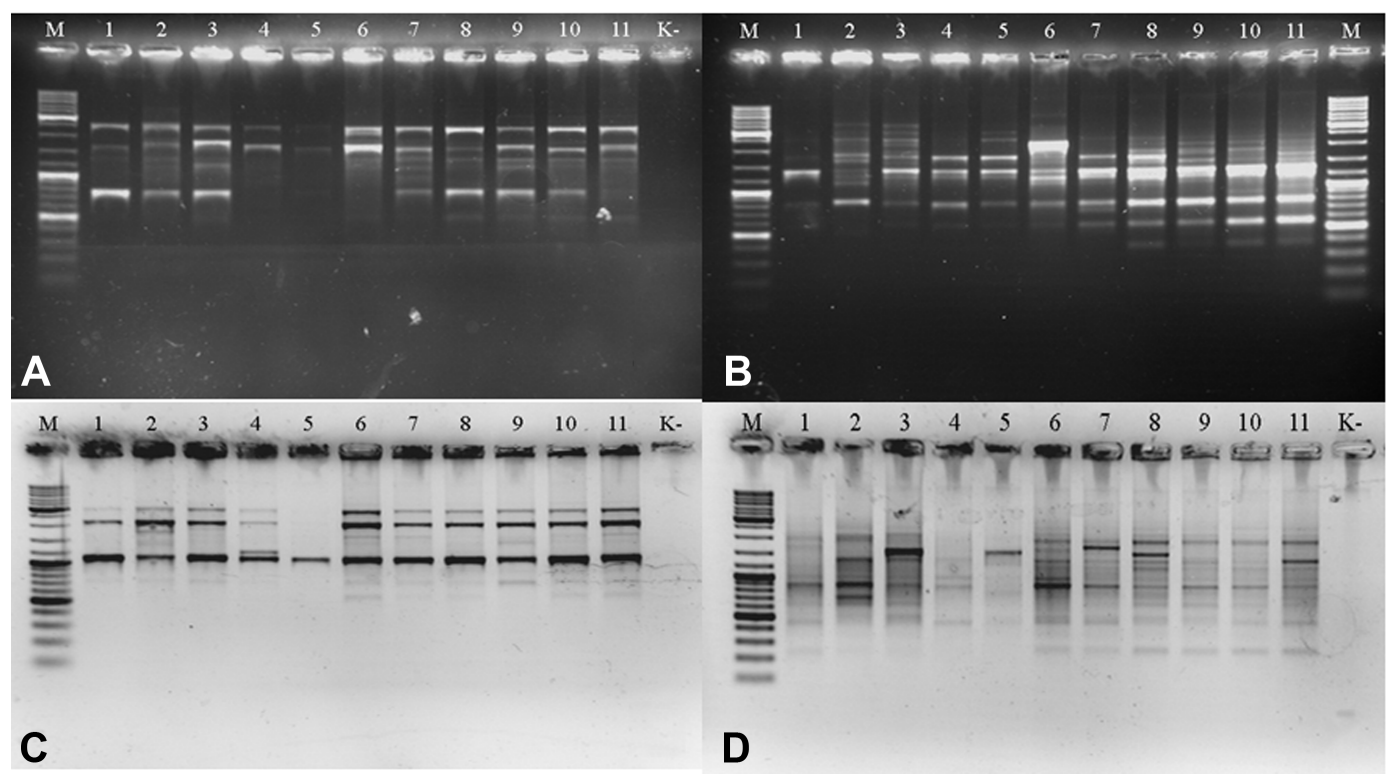

Fig. 2. Agarose gel electrophoresis of random amplified polymorphic DNA-based polymerase chain reaction: (A) OPA01, (B) OPA02, (C) OPB01, (D) OPA13, fingerprint patterns obtained from 11 Orobanche cumana populations from Serbia. Lane M, DNA molecular size marker (GeneRuler DNA LadderMix); lane 1, OC-2; lane 2, OC-3; lane 3, OC-4; lane 4, OC-5; lane 5, OC-6; lane 6, OC-7; lane 7, OC8; lane 8, OC-9; lane 9, OC-10; lane 10, OC-11; lane 11, OC-12. 
closely related.

\section{Results}

Plants of $O$. cumana were collected from sunflower fields located in four districts including North Bačka (Subotica, Feketić), West Bačka (Kula), South Banat (Vršac), and Bor District (Negotin) (Fig. 1). DNA was extracted from obtained seeds and was used for evalution of genetic diversity of population. For molecular analysis RAPD profiles were generated with OPA01, OPA02, OPA13, and OPB01 primers.

For each of the four primers, a polymorphic banding pattern was observed. RAPD analyses of these populations are shown in Fig. 2. Differences among populations were assessed visually based on migration patterns of the PCR products. The bands were clearly differentiated by agarose gel electrophoresis.

RAPD profiles obtained with OPA01 primer generated PCR products ranged in size from approximately $500 \mathrm{bp}$ to over 3,000 bp. Similar DNA patterns were observed for all tested populations, with two characteristic bands on 1,600 and 2,500 bp. The third band with size of $750 \mathrm{bp}$ was amplified for populations OC-2 (Vršac), OC-3 (Negotin), OC-4 (Subotica), OC-8 (Kula), OC-9 (Feketić), OC-10 (Subotica), and OC-11 (Kula), except for populations OC-5 (Kula) and OC-6 (Feketić), OC-7 (Subotica) and OC-12 (Feketić).

RAPD patterns obtained with OPB01 primer for all investigated populations showed very similar profiles indicating that this DNA marker is not very useful in determining genetic diversity. OPB01 primer gave reproducible genomic PCR profiles with bands of approximately $500 \mathrm{bp}$ to over 3,000 bp. The OPB01 primer provided amplification patterns that included three specific polymorphic bands $(550,2,100$, and $3,000 \mathrm{bp})$. Only the populations OC-5 and OC-6 obtained from Kula and Feketić, respectively (Fig. 2C, lanes 4 and 5) were found different from the other populations. Population OC-5 had unique bands on position $600 \mathrm{bp}$ and population OC-6 on position $550 \mathrm{bp}$, but no bands were observed on 2,100 bp and 3,000 bp which were characteristic for other populations.

RAPD DNA profiles generated with OPA02 primer were complex and varied significantly among the isolates (Fig. 2B) ranging from $400 \mathrm{bp}$ to over $6,000 \mathrm{bp}$. Visual analysis of OPA02 DNA profiles differentiated 11 DNA pattern profiles.

OPA13 primer sets gave reproducible RAPD DNA profiles with bands ranging from approximately $200 \mathrm{bp}$ to over 2,500 bp. Visual analysis of RAPD DNA profiles

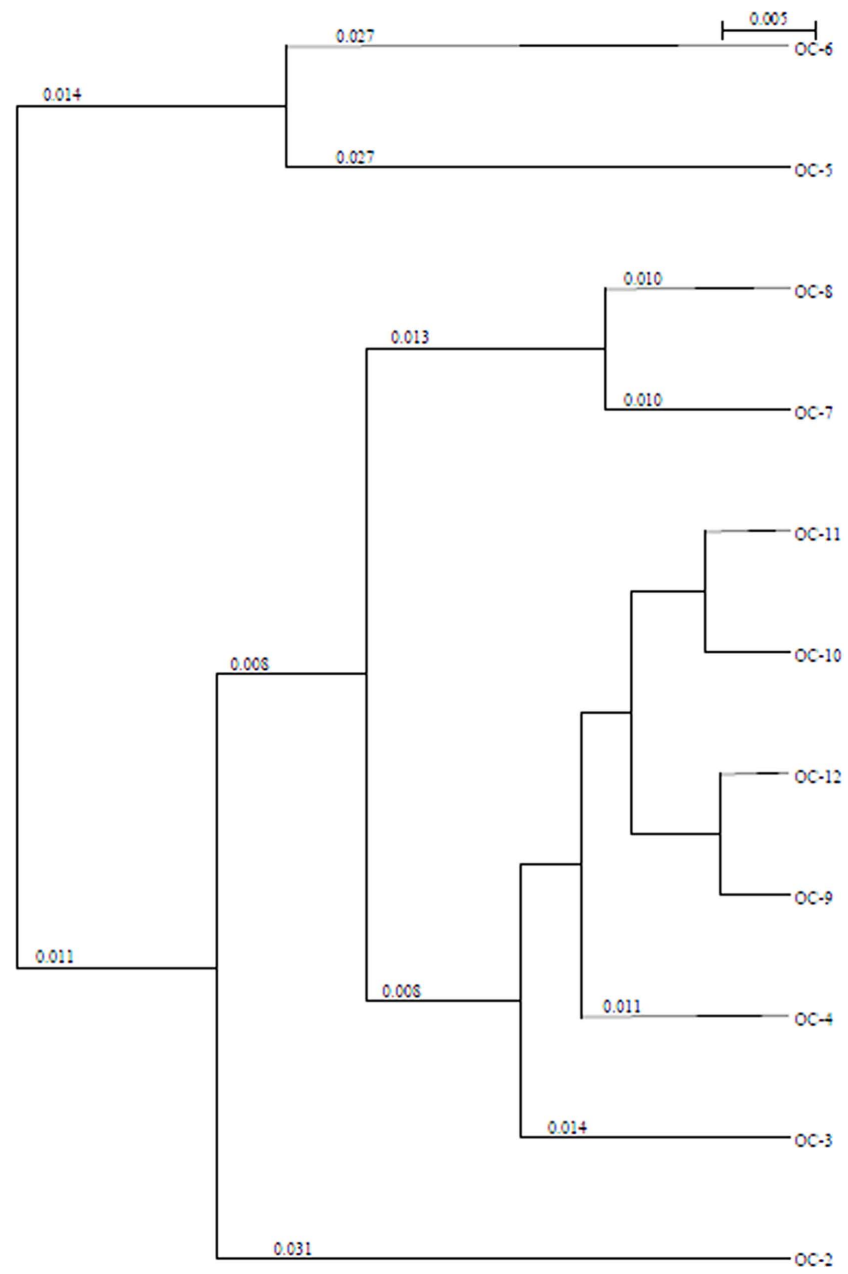

Fig. 3. Dendrogram of distances between Orobanche cumana populations tested for random amplified polymorphic DNA profiles. Bar represents the estimated relative distance between isolates.

obtained with OPA13 primer clearly differentiated seven DNA pattern profiles. A dendrogram produced by UPGMA clustering showed three different clusters (Fig. 3). The first group consisted of $O$. cumana populations OC-5 and OC- 6 obtained from Kula and Feketić, respectively. The second group consisted of populations OC-7 and OC- 8 from Subotica and Kula, and the third group consisted of populations OC-9, OC-10, obtained from Feketic and Subotica, and population OC-11 and OC-12 from Kula and Feketić. Negotin OC-3 and Subotica OC-4 populations were also included in this cluster. DNA profiles generated from $O$. cumana population OC-2 originating from Vršac did not group in any of the mentioned clusters.

For additional determination of genetic diversity of $O$. cumana populations, a molecular analysis of the $r b c L$ gene from O. cumana plants collected in Serbia was performed 


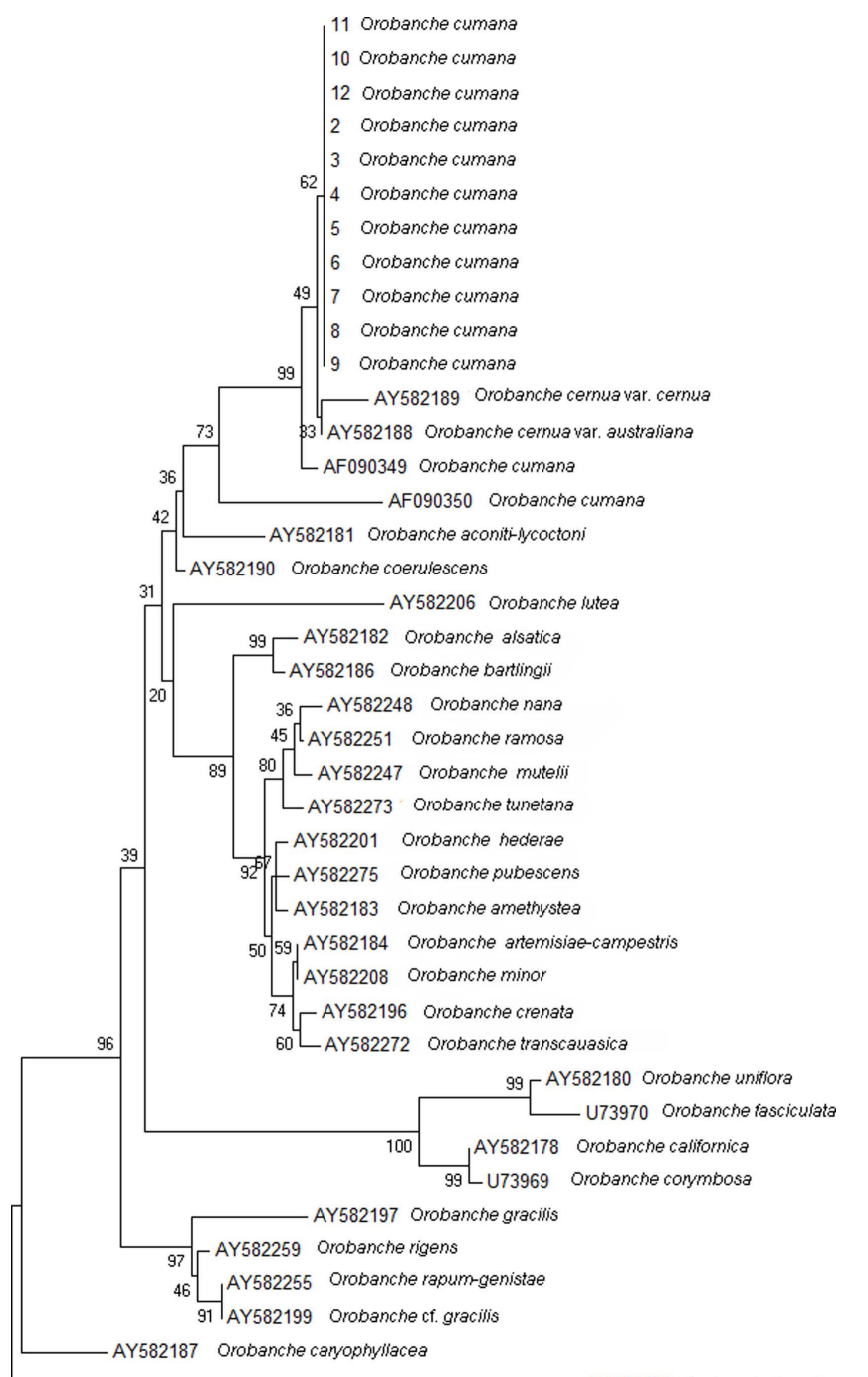

AY582269 Orobanche tecuril

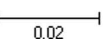

Fig. 4. Neighbor-joining tree showing the phylogenetic relationship of 11 populations of Orobanche cumana from Serbia and those of reference strains present in the NCBI databank, based on partial sequences of genes $r b c L$. Bootstrap values (expressed as percentages of 1,000 replications) are given at the nodes. Scale bar = estimated nucleotide substitutions per site is 0.005 .

and sequences are available in GenBank database under accession numbers KP222282-KP222292 (Table 1). The sequences of the $r b c L$ gene of $O$. cumana plants from Serbia did not match $100 \%$ with any of the published O. cumana $r b c L$ gene sequences in the NCBI database, they were grouped as a monophyletic cluster (Fig. 4). Partial $r b c L$ gene sequences from this study were compared with other Orobanche species representatives of diverse Orobanche genus sections obtained from NCBI database, and showed that sequences of representatives of populations from Ser-

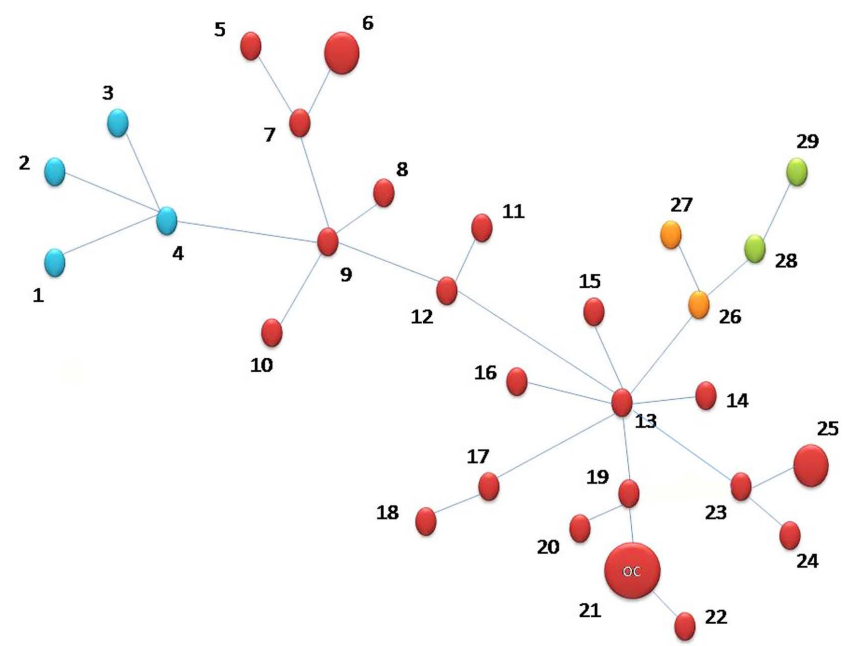

Fig. 5. Mini spanning tree splits genealogical network for representative species of four sections of Orobanche genus (section Orobanche colored in red, section Myzorrhiza colored in yellow, section Gymnocaulis colored in green and section Trionychon colored in blue) and populations of $O$. cumana from Serbia (designated as OC). Each strain is represented with separate node, size of a node is presented with the number of the isolates: 1, O. muteliiAY582247; 2, O. tunetana AY582273; 3, O. nana AY582248; 4, O. ramose AY582251; 5, O. crenata AY582196; 6, O. artemisiae-campestris AY582184 and O. minor AY582208; 7, O. transcaucasica AY582272; 8, O. hederae AY582201; 9, O. amethystea AY582183; 10, O. pubescens AY582275; 11, O. alsatica AY582182; 12, O. bartlingii AY582186; 13, O. coerulescens AY582190; 14, O. lutea AY582206; 15, O. aconiti-lycoctoni AY582181; 16, O. cumana AF090350; 17, O. caryophyllacea AY582187; 18, O. teucrii AY582269; 19, O. cernua var. australiana AY582188; 20, O. cernua var. cernua AY582189; 21, O. cumana (Serbian population); 22, O. cumana AF090349; 23, O. rigens AY582259; 24, O. gracilis AY582197; 25, O. rapum-genistae AY582255 and O. cf. gracilis AY582199; 26, O. californica AY582178; 27, O. corymbosa U73969; 28, O. fasciculata U73970; 29, O. uniflora AY582180.

bia were clustered in same clade with $O$. cumana and $O$. cernua species.

An MST generated from partial DNA sequences of $r b c L$ gene of $O$. cumana from Serbia and representative sequences data available in the NCBI, depicted the relationships among Orobanche spp. The MST constructed using statistical parsimony with split network revealed no ambiguous connections between species and clearly clustered four sections of Orobanche genus. Most haplotypic groups contained only one species except for haplotype $6(O$. artemisiae-campestris and O. minor), haplotype 21 (O. Cumana OC 2-12), and haplotype 25 (O. rapum-ganiste and O. cf. gracilis), resulting in 29 distinct haplotype groups. 
MST is shown in Fig. 5, where the colors represent four Orobanche sections, section Orobanche colored in red, section Myzorrhiza colored in yellow, section Gymnocaulis colored in green and section Trionychon colored in blue. The reconstructed MST agreed with the NJ phylogenetic tree and recovered hierarchical phylogenetic relationships between $O$. cumana and $O$. cernua. It is noticeable that sequences of $O$. cumana were located at the interior nodes of the tree and were linked with the two different $O$. cernua varietes.

\section{Discussion}

Different studies on the genetic diversity of $O$. cumana populations from various European countries have indicated that populations from eastern Europe belong to one main gene pool, while populations from Spain belong to a second main gene pool (Castejón-Muñoz et al., 1991; Gagne et al., 1998; Molinero-Ruiz et al., 2014; PinedaMartos et al., 2013). It was also discovered that the Spanish populations were closer to the Romanian population, than the Bulgarian and Turkish populations (Gagne et al., 1998). The authors reported low intrapopulation and high interpopulation genetic variation as well as little gene exchange between geographical regions (Gagne et al., 1998). In Spain, most of the populations had low intraand interpopulation diversity, with only a few populations with high intrapopulation genetic diversity (Pineda-Martos et al., 2013). In recent studies, Martín-Sanz et al. (2016), discovered two distant $O$. cumana gene pools, one in center and another in the south of the country. The RAPD technique was used to assess genetic diversity in Serbian populations using four different primers, and it showed high intrapopulation diversity. The OPA13 and OPA02 primers were more discriminative in differentiating the $O$. cumana populations than OPA01 and OPB01 primers. The UPGMA analyses revealed the existence of genetic variability among the populations which resulted in a phylogenetic tree where populations were grouped in four diverse clusters. Plants collected from northern Serbia (Subotica, Kula, and Feketić), showed more than one genomic pattern indicating that at least three different populations of O. cumana parasitize sunflower in this region. Populations from Negotin, located in eastern Serbia, suggested similar profiles as some isolates from northern Serbia.

It can be concluded that $O$. cumana plants collected from diverse agricultural regions in Serbia are members of the same population with great genetic heterogeneity. Our results differ from those obtained in other countries where high levels of variation among populations and low intra- population variability were found (Gagne et al., 1998). This could be explained by geographic position of sunflowergrowing areas which are located near the country borders and sunflower-growing areas in Romania, Bulgaria, and Hungary. The broomrape has very light seeds and can be easily spread by water, wind, animals and by humanderived agricultural and cultivation practices, as well as crop-seed trade and the use of contaminated sunflower seed stocks (Satovic et al., 2009), which can overpass spatial distances or barriers common in natural ecosystems (Pineda-Martos et al., 2014). Further, intensive gene flow among populations significantly influences genetic events and differences in all above-mentioned populations of $O$. cumana, which probably lead to high genetic heterogeneity in Serbian population of $O$. cumana. Close relation among the populations of $O$. cumana from Negotin and northern populations suggests that probably use of contaminated sunflower seed contributed to spread of specific genotypes. Genetic diversity among the populations suggests the possibility of seed introduction from different areas and genetic recombination between different populations (PinedaMartos et al., 2013). Seed exchange among diverse districts could give possibilities for genetic recombination between distant population which could lead to the intrapopulation diversity in Serbia. All of these gene exchange mechanisms involved may be a good path for creating new genetic variability and virulence change (Pineda-Martos et al., 2013). In this study, the use of the RAPD technique to assess genetic diversity was very useful in variability examination within and between $O$. cumana populations, which is important for improvement of crop breeding strategies for O. cumana control.

Many authors have previously suggested the use of $r b c L$ gene sequences in phylogenetic research at inter- and intraspecific genetic levels (Benharrat et al., 2000; Manen et al., 2004; Wolfe and dePamphilis, 1998). In the present study, the partial sequence of the $r b c L$ gene that encodes the large subunit of ribulose-1,5-bisphosphate carboxylase/oxygenase was also examined and found to be suitable for phylogenetic analysis of Orobanche species which is in accordance with Wolfe and dePhamilis (1998). Partial sequences of the $r b c L$ gene and constructed MST tree clearly divided Orobanche species into four sections of Orobanche genus and suggested that all O. cumana populations from Serbia were clustered in one monophyletic subcluster together with representative sequences of $O$. cumana and O. cernua. Close relationship between these two species was presented with direct connection of the nodes of the tree, suggesting a strong relationship between these two species. The MST tree provided further information about the relations 
among Orobanche species and showed existence of different $O$. cumana haplotypes. $O$. cumana populations from Serbia represent one haplotype and differ from $O$. cumana haplotype originated from France obtained from NCBI database. Although $r b c L$ gene sequences were found to be very informative at the interspecific level, it was interesting to reveal it can cluster distinct $O$. cumana haplotypes.

The $r b c L$ gene as a molecular marker did not have the resolution to display intrapopulation diversity, but it could be a valuable method for studying the evolution of geographically remote populations. Since RAPD analyses revealed intraspecific variations were present among populations in Serbia, further investigations are needed to study phylogenetic relations with populations from other countries. High genetic potential revealed in this research implicates that more virulent races could appear and that determination of broomrape genetic structure is very significant for new control strategies of this parasitic plant. It is important to note that the overall efficiency and effectiveness of weed control programs and also most appropriate means of combating the weeds will be enhanced by the knowledge on genetic relatedness or diversity available within local and regional populations and varieties of $O$. cumana.

\section{Conflicts of Interest}

No potential conflict of interest relevant to this article was reported.

\section{Acknowledgments}

The authors declare that they have no conflict of interests. This work was supported by the Ministry of Education and Science, and Technological development of Republic of Serbia (Contract No. 451-03-9/2021-14/200010).

\section{References}

Aćimović, M. 1977. Distribution of important sunflower diseases in Yougoslavia. Institute of Field and Vegetable Crops, Novi Sad, Yougoslavia. 17 pp.

Atanasova, R., Batchvarova, R., Todorovska, E. and Atanassov, A. 2005. Molecular study of broomrape (Orobanche spp.) by RAPD analyses. Biotechnol. Biotechnol. Equip. 19:51-60.

Benharrat, H., Delavault, P., Theodet, C., Figureau, C. and Thalouarn, P. 2000. rbcL plastid pseudogene as a tool for Orobanche (subsection Minores) identification. Plant Biol. 2:3439.

Bilgen, B. B., Barut, A. K. and Demirbaş, S. 2019. Genetic characterization of Orobanche cumana populations from the Thrace region of Turkey using microsatellite markers. Turk. J.
Bot. 43:38-47.

Calderón-González, Á., Pouilly, N., Muños, S., Grand, X., Coque, M., Velasco, L. and Pérez-Vich, B. 2019. An SSRSNP linkage map of the parasitic weed Orobanche cumana Wallr. including a gene for plant pigmentation. Front. Plant Sci. 10:797.

Castejón-Muñoz, M., Suso, M. J., Romero-Muñoz, F. and GarcíaTorres, L. 1991. Isoenzymatic study of broomrape (Orobanche cernua) populations infesting sunflower (Helianthus annuus). In: Proceedings of the 5th International Symposium of Parasitic Weeds, eds. by J. K. Ransom, L. J. Musselman, A. D. Worsham and C. Parker, pp. 313-319. International Maize and Wheat Improvement Center, Nairobi, Kenya.

Delavaault, P. and Thalouarn, P. 2002. The obligate root parasite Orobanche cumana exhibits several rbcL sequences. Gene 297:85-92.

Dor, E., Plakhine, D., Joel, D. M., Larose, H, Westwood, J. H., Smirnov, E., Ziadna, H. and Hershenhorn, J. 2020. A new race of sunflower broomrape (Orobanche cumana) with a wider host range due to changes in seed response to strigolactones. Weed Sci. 68:134-142.

Duca, M., Joiţa-Păcureanu, M., Port, A., Martea, R., Boicu, A., Rîşnoveanu, L. and Clapco, S. 2019. Genetic diversity analysis of sunflower broomrape populations from Republic of Moldova using ISSR markers. Rom. Agric. Res. 37:89-97.

Duca, M., Port, A., Boicu, A. and Șestacova, T. 2017. Molecular characterization of broomrape populations from Republic of Moldova using SSR markers. Helia 40:47-59.

Felsenstein, J. 1993. Phylogeny inference package version 3.5c. URL https://csbf.stanford.edu/phylip/ [13 August 2021].

Fernández-Aparicio, M., Reboud, X. and Gibot-Leclerc, S. 2016. Broomrape weeds. Underground mechanisms of parasitism and associated strategies for their control: a review. Front. Plant Sci. 7:135.

Gagne, G., Roeckel-Drevet, P., Grezes-Besset, B., Shindrova, P., Ivanov, P., Grand-Ravel, C., Vear, F., de Labrouhe, D. T., Charmet, G. and Nicolas, P. 1998. Study of the variability and evolution of Orobanche cumana populations infesting sunflower in different European countries. Theor. Appl. Genet. 96:1216-1222.

Huson, D. H. and Bryant, D. 2006. Application of phylogenetic networks in evolutionary studies. Mol. Biol. Evol. 23:254267.

Jebri, M., Ben Khalifa, M., Fakhfakh, H., Pérez-Vich, B. and Velasco, L. 2017. Genetic diversity and race composition of sunflower broomrape populations from Tunisia. Phytopathol. Mediterr. 56:421-430.

Joel, D. M., Benharrat, H., Portnoy, V. H. and Thalouarn, P. 1998. Molecular markers for Orobanche species: new approaches and their potential uses. In: Current Problems of Orobanche Researchers. Proceedings of the 4th International Workshop on Orobanche Research, eds. by K. Wegmann, L. J. Musselman and D. M. Joel, pp. 115-124. Institute for Wheat and Sunflower Dobroudja, Albena, Bulgaria. 
Katzir, N., Portnoy, V., Tzuri, G., Joel, D. M. and CastejónMuñoz, M. 1996. Use of random amplified polymorphic DNA (RAPD) markers in the study of the parasitic weed Orobanche. Theor. Appl. Genet. 93:367-372.

Malek, J., del Moral, L., Fernández-Escobar, J., Pérez-Vich, B. and Velasco, L. 2017. Racial characterization and genetic diversity of sunflower broomrape populations from northern Spain. Phytopathol. Mediterr. 56:70-76.

Manen, J.-F., Habashi, C., Jeanmonod, D., Park, J.-M. and Schneeweiss, G. M. 2004. Phylogeny and intraspecific variability of holoparasitic Orobanche (Orobanchaceae) inferred from plastid $r b c L$ sequences. Mol. Phylogenet. Evol. 33:482500.

Martín-Sanz, A., Malek, J., Fernández-Martínez, J. M., PérezVich, B. and Velasco, L. 2016. Increased virulence in sunflower broomrape (Orobanche cumana Wallr.) populations from southern Spain is associated with greater genetic diversity. Front. Plant Sci. 7:589.

Maširević, S. and Medić-Pap, P. 2009. Broomrape in Serbia from its occurence till today. Helia 32:91-100.

Molinero-Ruiz, L., García-Carneros, A. B., Collado-Romero, M., Raranciuc, S., Domínguez, J. and Melero-Vara, J. M. 2014. Pathogenic and molecular diversity in highly virulent populations of the parasitic weed Orobanche cumana (sunflower broomrape) from Europe. Weed Res. 54:87-96.

Moretti, M., Saracchi, M. and Farina, G. 2004. Morphological, physiological and genetic diversity within a small population of Cercospora beticola Sacc. Ann. Microbiol. 54:129-150.

Nei, M. and Li, W. H. 1979. Mathematical model for studying genetic variation in terms of restriction endonucleases. Proc. Natl. Acad. Sci. U. S. A. 76:5269-5273.

Paran, I., Gidoni, D. and Jacobsohn, R. 1997. Variation between and within broomrape (Orobanche) species revealed by RAPD markers. Heredity 78:68-74.

Parker, C. and Riches, C. R. 1993. Parasitic weeds of the world: biology and controls. CAB International, Wallingford, UK. 332 pp.

Pineda-Martos, R., Velasco, L., Fernández-Escobar, J., Fernán-
dez-Martínez, J. M. and Pérez-Vich, B. 2013. Genetic diversity of Orobanche cumana populations from Spain assessed using SSR markers. Weed Res. 53:279-289.

Pineda-Martos, R., Velasco, L. and Perez-Vich, B. 2014. Identification, characterisation and discriminatory power of microsatellite markers in the parasitic weed Orobanche cumana. Weed Res. 54:120-132.

Roman, B. and Rubiales, D. 1999. Molecular analysis of Orobanche crenata populations from southern Spain. In: Resistance to Orobanche: the state of the art, eds. by J. I. Cubero, M. T. Moreno, D. Rubiales and J. Sillero, pp. 99-108. Junta de Andalucía, Sevilla, Spain.

Satovic, Z., Joel, D. M., Rubiales, D., Cubero, J. I. and Román, B. 2009. Population genetics in weedy species of Orobanche. Australas. Plant Pathol. 38:228-234.

Tamura, K., Stecher, G., Peterson, D., Filipski, A. and Kumar, S. 2013. MEGA6: molecular evolutionary genetics analysis version 6.0. Mol. Biol. Evol. 30:2725-2729.

Yang, C., Fu, F., Zhang, N., Wang, J., Hu, L., Islam, F., Bai, Q., Yun, X. and Zhou, W. 2020. Transcriptional profiling of underground interaction of two contrasting sunflower cultivars with the root parasitic weed Orobanche cumana. Plant Soil 450:303-321.

Young, N. D., Steiner, K. E. and dePamphilis, C. W. 1999. The evolution of parasitism in Scrophulariaceae/Orobanchaceae: plastid gene sequences refute an evolutionary transition series. Ann. Missouri Bot. Gard. 86:876-893.

Williams, J. G., Kubelik, A. R., Livak, K. J., Rafalski, J. A. and Tingey, S. V. 1990. DNA polymorphisms amplified by arbitrary primers are useful as genetic markers. Nucleic Acids Res. 18:6531-6535.

Wolfe, A. D. and dePamphilis, C. W. 1997. Alternate paths of evolution for the photosynthetic gene $r b c L$ in four nonphotosynthetic species of Orobanche. Plant Mol. Biol. 33:965-977.

Wolfe, A. D. and dePamphilis, C. W. 1998. The effect of relaxed functional constraints on the photosynthetic gene rbcL in photosynthetic and nonphotosynthetic parasitic plants. Mol. Biol. Evol. 15:1243-1258. 